\title{
SOIL ORGANIC CARBON STOCKS IN GRANULOMETRIC FRACTIONS UNDER USE AND MANAGEMENT SYSTEMS WITH SWINE AND POULTRY MANURE
}

\author{
Luiz Paulo Rauber ${ }^{1}$, Andréia Patrícia Andrade ${ }^{1}$, Álvaro Luiz Mafra ${ }^{1}$
}

${ }^{1}$ Universidade do Estado de Santa Catarina-UDESC. E-mail: sr_roiber@yahoo.com.br, andreaipatricia74@yahoo.com.br, alvaro.mafra@udesc.br

\begin{abstract}
The swine and poultry production generates a large volume of residue, which can have positive and negative impacts on the soil, depending on the conditions of use and on the amount of manure added. We evaluated the influence of swine slurry and poultry litter on the total organic carbon (TOC) and its distribution in granulometric fractions and in aggregate size classes of a Nitossolo Vermelho Eutróférrico (Alfisol). The areas analyzed were maize for silage under no-tillage (M7 years), maize for silage under conventional tillage (M20 years), annual pasture with chiseling (P3 years), annual pasture with chiseling (P15 years), permanent pasture without tillage (PP20 years), yerba mate without tillage (YM20 years), both compared to native forest (NF) and native pasture (NP). TOC levels were lower in the cultivated areas compared to the soil under natural vegetation, indicating that the agricultural use triggers the degradation process and loss of carbon. The POC expresses the sensitivity of the system as to the changes in carbon stock in the soil.
\end{abstract}

Keywords: Biofertilizer, organic matter, soil management

\section{ESTOQUES DE CARBONO ORGÂNICO EM FRAÇÕES GRANULOMÉTRICAS DO SOLO EM SISTEMAS DE USO E MANEJO COM FERTILIZANTES ORGÂNICOS DE SUÍNOS E AVES}

\section{RESUMO}

A produção de suínos e aves produz um grande volume de resíduo, que pode ter impactos positivos e negativos no solo, dependendo das condições de uso e da quantidade de estrume adicionada. Avaliou-se a influência do uso de dejetos de suínos e cama de aves sobre o carbono orgânico total (COT) e sua distribuição em frações granulométricas e em classes de tamanho agregado de Nitossolo Vermelho 
Eutróférrico. As áreas analisadas foram o milho para silagem em plantio direto (M7 anos), milho para silagem sob plantio convencional (M20 anos), pastagem anual com escarificação (P3 anos), pastagem anual com esqueleto (P15 anos), pastagem permanente sem lavoura (PP20 anos), erva-mate sem plantio direto (YM20 anos), ambos comparados à floresta nativa (NF) e pastagem nativa (PN). Os níveis de COT foram menores nas áreas cultivadas em comparação com o solo sob vegetação natural, indicando que o uso agrícola desencadeia o processo de degradação e perda de carbono. O COP expressa a sensibilidade do sistema quanto às mudanças no estoque de carbono no solo.

Palavras-chave: Biofertilizante, matéria orgânica, manejo do solo

\section{INTRODUCTION}

The conversion of natural ecosystems into agricultural systems can involve a series of changes in soil components, and agricultural sustainability is influenced by the management adopted, which may affect soil organic matter (SOM) addition and decomposition rates (LOSS et al., 2009). Usually, the reduction in the organic carbon stocks in cultivated soil compared to the native forests can be attributed to the increase in soil erosion and organic matter oxidation, as well as the low input of organic material (HOUGHTON et al., 1991).

In the western region of Santa Catarina, swine and poultry farming is typical of small farms, where manure is used as organic fertilizer in the agricultural production areas. The contribution of these materials to the availability of organic carbon and nutrients depends on the amount of manure added and the decomposition rate of the material (BRANCALIÃO \& MORAIS, 2008). The organic fertilizers may alter functional aspects of the SOM, expressed by changes in its labile or stable fractions, which may influence the atmospheric carbon capture, as well as affect soil physical, chemical and biological properties.

One of the ways to evaluate these changes is the granulometric fractionation of the SOM (CAMBARDELLA \& ELLIOTT, 1992) with separation of particulate organic carbon (POC) and mineral-associated organic carbon (MAOC). The POC is the fraction of the SOM separated by dispersion and sieving of the soil associated to the sand fraction (POC> $>3 \mu \mathrm{m}$ ), being characterized as particles derived from plant residues and hyphae with recognizable cellular structure, whose permanence in the soil is conditioned to the physical protection provided by aggregates (GOLCHIN et al., 1994). The OCam 
is the fraction of SOM associated with silt and clay fractions (MAOC $<53 \mu \mathrm{m}$ ), interacting with the surface of mineral particles, forming organo-mineral complexes, which results in higher colloidal protection. Thus, the granulometric fractionation of the SOM can aid in the evaluation of the modifications arising from the soil use due to the sensitivity of these fractions to the soil management (CAMBARDELLA \& ELLIOTT, 1992; BAYER et al., 2004).

Management systems that promote different inputs of plant biomass and the application of manure can have different effects on the particulate fraction of the SOM, and the latter can be used as a tool to evaluate the quality of the soil (CONCEIÇÃO et al., 2005). The objective of this work was to evaluate the effect of swine slurry and poultry litter, in different systems of use and management of a Alfisol, regarding the total organic carbon contents, the carbon storage in the particulate fraction and in the mineral-associated fraction, and the distribution of the carbon contained in aggregate size classes.

\section{MATERIAL AND METHODS}

The study was carried out in Concórdia-SC, southern Brazil, in selected areas of the same watershed, being the soil classified as Nitossolo Vermelho Eutróférrico (Alfisol), derived from basalt (EMBRAPA, 2013). The soil uniformity was previously evaluated by means of auger, to a depth of 1 meter, identifying similar conditions of soil depth, relief, texture and soil moist color (10 R 3/6). The climate is classified as humid subtropical (Cfa), according to the classification of Köppen (EMBRAPA, 2004).

The soil use systems consisted of different forms of cultivation, receiving application of swine slurry (SS) (stored for three months in anaerobic digestion lagoon, in the finishing swine system, and then applied to the soil surface with a tractor-driven equipment at an annual rate of $50 \mathrm{~m}^{3} \mathrm{ha}^{-1}$ based on the current environmental criteria (FATMA, 2000) and poultry litter (PL), removed from poultry houses at every three batches and applied to the soil surface once a year at the rate of $16 \mathrm{~m}^{3} \mathrm{ha}^{-1}$ ).

The systems of land use and management consisted of areas with different forms of cultivation and application of organic fertilizers based on swine slurry (SS) and poultry litter (Table 1), namely: maize for silage with 7 years of manure application (M7); maize for silage with 20 years of application (M20); annual pasture with 3 years of application (P3); annual pasture with 15 years of application (P15); perennial pasture with 20 years of application without grazing (PP20); yerba mate with 20 years of application (YM20); native forest (NF) and native pasture without the application of manure (P0). 
Table 1. Characteristics of the studied areas under different systems of use and management with application of animal manure to a Alfisol. Concordia-SC.

\begin{tabular}{l}
$\begin{array}{l}\text { Soil use and management } \\
\text { system }\end{array}$ \\
Maize under no-tillage (M7) \\
\hline $\begin{array}{l}\text { Maize under conventional tillage } \\
\text { (M20) }\end{array}$
\end{tabular}

\section{Description ${ }^{1}$}

Maize (Zea mays) cultivation for silage under no-tillage system (2 annual crops), with 7 years of application of swine slurry (SS) every 4 months; poultry litter $^{2}$ (PL) applications (once a year); fallow in winter. ${ }^{3}$ Carbon input of $16 \mathrm{Mg} \mathrm{ha}^{-1}$ over 7 years from swine and poultry manure.

Maize cultivation for silage in a conventional tillage system (2 annual crops), with 20 years of SS application every 4 months; PL application (once a year); Ryegrass cultivation in winter. ${ }^{3}$ Carbon input of $46 \mathrm{Mg} \mathrm{ha}^{-1}$ over 20 years from swine and poultry manure.

${ }^{4}$ (Avena sativa) and ryegrass (Lolium multiflorum) cultivation in winter and millet (Pennisetum americanum L.) and Sudan grass Annual pasture with chiseling (P3) (Shorghum sudanense L.) in the summer, with an annual chiseling, with 3 years' application of SS every 4 Months; ${ }^{2} \mathrm{PL}$ application (once a year). ${ }^{3}$ Carbon input of $6.9 \mathrm{Mg}$ ha $^{-1}$ over 3 years from swine and poultry manure.

Cultivation of oats and ryegrass in the winter and millet and sudan

Annual pasture with chiseling (P15) grass in the summer, with one annual chiseling, 15 years of application of SS every 4 months; ${ }^{2} \mathrm{PL}$ application (once a year). ${ }^{3}$ Carbon contribution of $34.5 \mathrm{Mg} \mathrm{ha}^{-1}$ for 15 years, from swine and poultry manure.

Perennial pasture of ryegrass, oats and fodder radish (Raphanus

Permanent pasture without tillage (PP20) sativus) without grazing, with annual cutting (tractor and brushcutter), with 20 years of SS application; ${ }^{2} \mathrm{PL}$ application (once a year). ${ }^{3}$ Carbon input of $46 \mathrm{Mg} \mathrm{ha}^{-1}$ over 20 years from swine and poultry manure.

Cultivation of yerba mate (Ilex paraguariensis) and ryegrass

Yerba mate without tillage (YM20) between the lines; without grazing, with 20 years of SS application; ${ }^{2} \mathrm{PL}$ application (once a year); both organic fertilizers applied between the lines. ${ }^{3}$ Carbon input of $46 \mathrm{Mg} \mathrm{ha}^{-1}$ over 20 years, from swine and poultry manure.

\begin{tabular}{l|l}
\hline Native forest (NF) & Native forest without anthropic interference. \\
\hline Native pasture (NP) & $\begin{array}{l}\text { Native pasture, without application of organic fertilizers from } \\
\text { swine and poultry manure. }\end{array}$ \\
\hline
\end{tabular}

${ }^{1}$ Soil acidity correction with limestone is done every 3 years, when necessary; ${ }^{2}$ Poultry litter obtained after three production batches of broilers; ${ }^{3}$ Carbon input obtained from SS (density $1.014 \mathrm{~g} \mathrm{~L}^{-1}$, carbon content of $9 \%$ and dry mass of $3 \%$ ) and PL (density $0.29 \mathrm{~g} \mathrm{~L}^{-1}$, carbon content of $30 \%$ and dry mass $75 \%$ ), according to data obtained from Scherer et al. 1995, CQFS$\mathrm{RS} / \mathrm{SC}, 2004 .{ }^{4}$ Stocking rate: $35-40$ cattle units $\mathrm{ha}^{-1}$;

In each area, eight soil samples, considered as pseudo replications (SBCS, 2012), were collected in two transects with points spaced at 10 meters. Sampling was conducted in September 2009 in three 
layers $0-5 ; 5-10$ and 10-20 cm. For soil total organic carbon (TOC) analysis 10 sub-samples were collected, around each point of the transect, with the use of an auger, and for each depth, the soil was homogenized obtaining a composite sample. The particulate organic carbon (POC) was fractionated from the mixture of $20 \mathrm{~g}$ of soil and $60 \mathrm{~mL}$ of sodium hexametaphosphate $\left(5 \mathrm{~g} \mathrm{~L}^{-1}\right)$, shaken for 16 hours and the suspension passed through a 53 $\mu \mathrm{m}$ sieve (CAMBARDELLA \& ELLIOT, 1992).

After fractionation, the samples were dried at $60{ }^{\circ} \mathrm{C}$, grounded in porcelain mortar. The carbon content within the aggregates (C-aggregates) was analyzed after the evaluation of the stability of aggregates, determined by wet sieving method in hand sort samples sieved between 8.0 and $4.75 \mathrm{~mm}$, according to the method described by Kemper \& Chepil (1965). The aggregates were separated into three classes retained in the sieves between 8.0 and $4.75 \mathrm{~mm}$ (class 1), between 4.75 and $2 \mathrm{~mm}$ (class 2) and less than $2.0 \mathrm{~mm}$ (class 3), being dried at $60^{\circ} \mathrm{C}$ for further quantification of organic carbon. The organic carbon determinations (TOC, POC, C-aggregates) were conducted according to the methodology of Tedesco et al. (1995), by wet combustion, with oxidation by potassium dichromate and titration with ferrous sulfate.

The stocks of TOC $\left(\mathrm{Mg} \mathrm{ha}^{-1}\right)$ were calculated taking into account the values of soil density in the three depths. The POC stocks were calculated considering the particulate mass retained in the sieve used to determine the POC. The stock of mineral associated organic carbon (MAOC) was calculated by the difference between TOC and POC stocks $\left(\mathrm{Mg} \mathrm{ha}^{-1}\right)$. The volumetric ring samples for determination of soil density and aggregates to evaluate the stability of aggregates were collected in trenches of $20 \times 20$ $\mathrm{cm}$.

The effect of different soil use systems and times of application of organic fertilizers on the organic carbon forms was evaluated in a relative manner by calculating the carbon management index (CMI), represented by the formula: CMI= CEI x LI x 100, where CEI represents the carbon efficiency index and LI the lability index, calculated by the formulas: $\mathrm{CEI}=\mathrm{TOC}_{\text {treatment }} / \mathrm{TOC}_{\text {native forest }}$ and $\mathrm{LI}=$

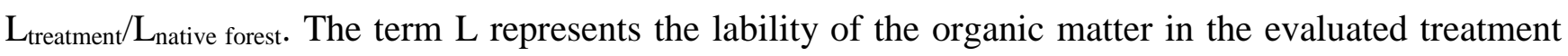
( $\mathrm{L}_{\text {treatment }}$ ) in relation to the lability of the organic matter of the reference system ( $\mathrm{L}_{\text {native forest }}$ ). The lability is represented by the POC concentration (VIEIRA et al., 2007).

The results were submitted to analysis of variance using the $\mathrm{F}$ test in a completely randomized model, with evaluation of the treatments effect in each depth and comparison of means by the " $t$ " test (P $<0.05)$, using statistical software SAS, version 9.1 (2007). 


\section{RESULTS AND DISCUSSION}

Total organic carbon (TOC) concentrations were influenced in all systems of use and management in the three evaluated depths $(0-5,5-10$ and 10-20 cm) (Table 2). At the 0-5 cm depth, the M20 and M7 management systems presented the lowest TOC contents in relation to the other evaluated systems, except for P15, and this can be attributed to the exportation of plant material from the area. The use and management system P15 had the lowest TOC concentration in the $0-5 \mathrm{~cm}$ depth, which may be related to the intensive grazing in that area, related to the high stocking rate of dairy cattle throughout 15 years.

In the 5-10 cm depth the use and management systems M7, M20, P15 and P0 presented lower TOC concentrations in relation to P3 and PP20, except for YM20 that was managed without soil tillage and with grass cover between mate lines. The more intensive use of the soil in the maize crops, carried out with no-tillage in the M7 and conventional tillage in the M20, both destined for silage production, and in the pastures P15 and P0, managed with intense grazing, resulted in low soil organic carbon concentration.

In general, the long term use of swine slurry and poultry manure did not increase soil organic carbon concentrations. Arruda et al. (2008) did not observe changes in organic carbon concentrations even with the application of high rates $\left(200 \mathrm{~m}^{3} \mathrm{ha}^{-1}\right)$ of swine slurry for nine consecutive years on a Rhodic Kandiudox. These results can be justified by the increase of the microbial activity in the soil that results in mineralization of the organic matter. Scherer et al. (2010) also did not observe an increase in OM concentration in three soils derived from basalt that received swine slurry for more than 20 years in the west of Santa Catarina. This result was attributed to the low dry matter (mean of $30 \mathrm{~g} \mathrm{dm}^{-3}$ ) and organic carbon concentrations in the swine slurry (SCHERER et al., 1996).

TOC stocks of the areas with twenty years of application and with no soil mobilization (YM20 and P0) were higher in relation to the other areas, reaching 14.3 and $14.4 \mathrm{Mg} \mathrm{ha}^{-1}$, respectively, in the surface layer (Table 2), but smaller than in the native forest, where $25.7 \mathrm{Mg} \mathrm{ha}^{-1}$ was verified, a variation similar to that observed with TOC concentrations.

In the three studied depths, NF presented the highest TOC stock in comparison to the use and management systems, which received animal manure and native pasture (NP) (Table 2). Thus, agricultural uses independently of management and of times of application of organic fertilizers, reduced the carbon stocks in relation to the soil under native vegetation. Rangel \& Silva (2007), studying carbon stocks under different use and management systems on a highly weathered soil (oxisol), found that soil use with afforestation, pasture and maize crop reduced the carbon content by $28 \%$ in relation to the soil 
under native forest. These results indicate that agricultural use can reduce soil carbon stocks in relation to the natural condition of native forest, even in conservationist soil management.

Table 2. Total organic carbon concentration (TOC), total organic carbon stock (TOCs) and soil density (SD) in areas under different systems of use and management with application of swine and poultry manure on a Alfisol.

\begin{tabular}{|c|c|c|c|}
\hline Treatments & TOC $\left(\mathrm{g} \mathrm{kg}^{-1}\right)$ & TOCs $\left(\mathrm{Mg} \mathrm{ha}^{-1}\right)$ & SD $\left(\mathrm{g} \mathrm{cm}^{-3}\right)$ \\
\hline & \multicolumn{3}{|c|}{ 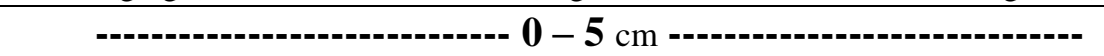 } \\
\hline M7 & $18.1 \mathrm{c}$ & $11.5 \mathrm{~cd}$ & 1.27 \\
\hline M20 & $18.8 \mathrm{c}$ & $11.7 \mathrm{~cd}$ & 1.24 \\
\hline P3 & $22.5 \mathrm{~b}$ & $13.4 \mathrm{bc}$ & 1.18 \\
\hline P15 & $15.0 \mathrm{~d}$ & $10.1 \mathrm{~d}$ & 1.34 \\
\hline PP20 & $23.8 \mathrm{~b}$ & $11.8 \mathrm{~cd}$ & 0.99 \\
\hline YM20 & $24.8 \mathrm{~b}$ & $14.3 \mathrm{~b}$ & 1.15 \\
\hline $\mathrm{NF}$ & $63.1 \mathrm{a}$ & $25.7 \mathrm{a}$ & 0.81 \\
\hline $\mathrm{P} 0$ & $23.8 \mathrm{~b}$ & $14.4 \mathrm{~b}$ & 1.20 \\
\hline \multirow[t]{2}{*}{$C V^{*}(\%)$} & 10.01 & 15.23 & 7.81 \\
\hline & \multicolumn{3}{|c|}{ 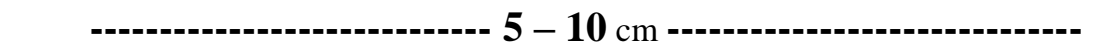 } \\
\hline M7 & $15.3 \mathrm{~cd}$ & $9.3 \mathrm{c}$ & 1.23 \\
\hline M20 & $16.6 \mathrm{~cd}$ & $10.6 \mathrm{bc}$ & 1.28 \\
\hline P3 & $20.1 \mathrm{~b}$ & $12.4 \mathrm{~b}$ & 1.22 \\
\hline P15 & $14.1 \mathrm{~d}$ & $9.5 \mathrm{c}$ & 1.34 \\
\hline PP20 & $18.2 \mathrm{bc}$ & $10.1 \mathrm{c}$ & 1.11 \\
\hline YM20 & $16.0 \mathrm{~cd}$ & $10.3 \mathrm{c}$ & 1.28 \\
\hline $\mathrm{NF}$ & $49.3 \mathrm{a}$ & $24.1 \mathrm{a}$ & 0.97 \\
\hline $\mathrm{P} 0$ & $15.6 \mathrm{~cd}$ & $9.2 \mathrm{c}$ & 1.18 \\
\hline \multirow[t]{2}{*}{$C V^{*}(\%)$} & 14.24 & 15.34 & 7.19 \\
\hline & \multicolumn{3}{|c|}{ 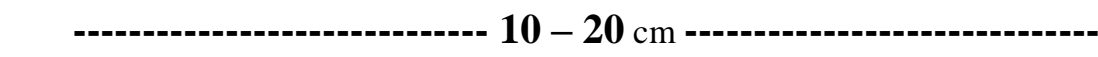 } \\
\hline M7 & $21.7 \mathrm{~d}$ & $26.5 \mathrm{~cd}$ & 1.22 \\
\hline M20 & $22.1 \mathrm{~d}$ & $26.7 \mathrm{~cd}$ & 1.21 \\
\hline P3 & $28.7 \mathrm{~b}$ & $32.7 \mathrm{~b}$ & 1.14 \\
\hline P15 & $21.5 \mathrm{~d}$ & $26.9 \mathrm{~cd}$ & 1.25 \\
\hline PP20 & $25.6 \mathrm{c}$ & $29.4 \mathrm{c}$ & 1.15 \\
\hline YM20 & $21.4 \mathrm{~d}$ & $26.0 \mathrm{~d}$ & 1.21 \\
\hline $\mathrm{NF}$ & $36.6 \mathrm{a}$ & $37.4 \mathrm{a}$ & 1.03 \\
\hline $\mathrm{P} 0$ & $23.3 \mathrm{~cd}$ & $25.7 \mathrm{~d}$ & 1.10 \\
\hline$C V^{*}(\%)$ & 9.34 & 11.46 & 6.08 \\
\hline
\end{tabular}

Studied areas: maize for silage under no-tillage (M7 years), maize for silage under conventional tillage (M20 years), annual pasture with chiseling (P3 years), annual pasture with chiseling (P15 years), permanent pasture without tillage (PP20 years), yerba mate without tillage (EM20 years), both compared to native forest (NF) and native pasture (NP). Means followed by different letters in the column differ from each other by the $t$ test $(\mathrm{P}<0.05)$. ${ }^{*} \mathrm{CV}$ : Coefficient of variation.

The use and management systems with maize (M7 and M20) had similar organic carbon concentration and stock, in the three evaluated depths (Table 2). These treatments presented low TOC 
concentrations in comparison with NF, a fact that can be related to the high biomass exportation, due to two annual silage harvests. In M20 conventional soil tillage is adopted and M7 remains in winter fallow, practices that can reduce organic carbon accumulation in the soil (BAYER et al., 2000).

OC concentrations in the soil particulate fraction were influenced by use and management systems, especially in the $0-5 \mathrm{~cm}$ depth, ranging from 46.3 to $94.3 \mathrm{~g} \mathrm{~kg}^{-1}$ in P15 and NF, respectively (Table 3). This indicates that the POC is a sensitive indicator to the changes caused by the management systems, making it possible to verify short term effects (BAYER et al., 2001, 2002). At 5-10 cm depth, M20 and P3 had the highest carbon content in the particulate fraction in relation to the other treatments, and were similar to the NF. In the 10-20 cm depth only YM20 and P0 differed from the NF. In all treatments, the particulate OC concentrations decreased in depth, showing that the carbon of this fraction was influenced by plant residues or manure added to the soil surface.

Considering the 0-20 cm depth, POC concentrations were more efficient than TOC to evaluate the differences between treatments. Loss et al. (2009) working on an Ultisol under different uses observed that POC concentration was the best quality indicator of SOM considering short term changes due to management practices.

Analyzing pasture use and management systems, P0 had similar POC concentrations to P15 and PP20 (Table 3), what can be attributed to the well-developed and well distributed root system of the grasses (in P0), which allows high soil carbon deposition by roots (RANGEL \& SILVA, 2007).

The native forest had the highest concentrations of carbon in the particulate fraction, compared to the other use and management systems, except in relation to P3 and M20, which were equivalent to the natural vegetation in the mean of the three depths. The M20 area had higher POC content than M7 (Table 3). When comparing management systems that receive manure for 20 years, M20 was similar to YM20 and PP20. The lowest POC concentration found in M7 may be due to its low input of plant residues, considering high biomass exportation by silage and fallow during the winter, while the M20 area presented oat crop.

The particulate carbon stock in the native forest was higher than in the other treatments, at all evaluated depths (Table 3).

The highest particulate carbon concentrations in the NF and P0 may be associated to their permanent soil cover and absence of soil tillage. These conditions reduce SOM decomposition and improve its stabilization by the formation of more stable aggregates (VEZZANI \& MIELNICKZUK, 2011). 
Table 3. Particulate organic carbon (POC) concentrations and particulate organic carbon stocks (POCs) in areas under different use and management systems with swine slurry and poultry manure Alfisol.

\begin{tabular}{|c|c|c|c|c|c|}
\hline \multirow{2}{*}{ Treatments } & \multicolumn{3}{|c|}{ Depth $(\mathrm{cm})$} & \multirow{2}{*}{$\begin{array}{l}\text { Weighted } \\
\text { average }\end{array}$} & \multirow{2}{*}{ CV\% * } \\
\hline & $0-5$ & $5-10$ & $10-20$ & & \\
\hline & -.-.- & & $\mathbf{O C}(\mathrm{g} \mathrm{kg}$ & & \\
\hline M7 & $59.1 \mathrm{~cd}$ & $28.2 \mathrm{~b}$ & $34.6 \mathrm{ab}$ & $39.1 \mathrm{c}$ & 20.01 \\
\hline M20 & $71.0 \mathrm{bc}$ & $60.3 \mathrm{a}$ & $38.2 \mathrm{ab}$ & $51.9 \mathrm{ab}$ & 16.23 \\
\hline P3 & $70.4 \mathrm{bc}$ & $50.7 \mathrm{a}$ & $41.5 \mathrm{ab}$ & $51.0 \mathrm{ab}$ & 30.41 \\
\hline P15 & $46.3 \mathrm{~d}$ & $37.0 \mathrm{~b}$ & $34.4 \mathrm{ab}$ & $38.0 \mathrm{c}$ & 13.54 \\
\hline PP20 & $67.0 \mathrm{c}$ & $35.4 \mathrm{~b}$ & $31.9 \mathrm{ab}$ & $41.5 \mathrm{bc}$ & 9.65 \\
\hline YM20 & $84.3 \mathrm{ab}$ & $31.2 \mathrm{~b}$ & $27.6 \mathrm{~b}$ & $42.7 \mathrm{bc}$ & 19.76 \\
\hline NF & $94.3 \mathrm{a}$ & $60.1 \mathrm{a}$ & $46.8 \mathrm{a}$ & $62.0 \mathrm{a}$ & 12.58 \\
\hline P0 & $58.8 \mathrm{~cd}$ & $36.3 \mathrm{~b}$ & $28.1 \mathrm{~b}$ & $37.8 \mathrm{c}$ & 14.67 \\
\hline \multirow{2}{*}{$C V^{*}(\%)$} & 24.34 & 28.84 & 41.93 & & \\
\hline & \multicolumn{5}{|c|}{ Sum $0-20 \mathrm{~cm}$} \\
\hline M7 & $3.4 \mathrm{cde}$ & $1.2 \mathrm{~d}$ & $\begin{array}{r}\text { OCs }\left(\mathrm{Ms}_{\varepsilon}\right. \\
2.7 \mathrm{bcd}\end{array}$ & 7.4 cde & 4.34 \\
\hline M20 & $3.1 \mathrm{de}$ & $2.3 \mathrm{bc}$ & $2.1 \mathrm{~cd}$ & $7.7 \mathrm{cde}$ & 537 \\
\hline P3 & $3.7 \mathrm{~cd}$ & $2.8 \mathrm{~b}$ & $3.6 \mathrm{bc}$ & $10.2 \mathrm{bc}$ & 10.32 \\
\hline P15 & $1.9 \mathrm{e}$ & $1.4 \mathrm{~cd}$ & $2.2 \mathrm{~cd}$ & $5.5 \mathrm{de}$ & 5.21 \\
\hline PP20 & $2.8 \mathrm{de}$ & $0.9 \mathrm{~d}$ & $1.5 \mathrm{~d}$ & $5.2 \mathrm{e}$ & 4.68 \\
\hline YM20 & $4.7 \mathrm{bc}$ & $1.6 \mathrm{~cd}$ & $2.1 \mathrm{~cd}$ & $8.3 \mathrm{~cd}$ & 8.91 \\
\hline NF & $11.6 \mathrm{a}$ & $6.0 \mathrm{a}$ & $7.3 \mathrm{a}$ & $25.0 \mathrm{a}$ & 7.87 \\
\hline P0 & $6.3 \mathrm{~b}$ & $2.8 \mathrm{~b}$ & $3.9 \mathrm{~b}$ & $13.0 \mathrm{~b}$ & 8.17 \\
\hline$C V^{*}(\%)$ & 37.63 & 43.73 & 41.99 & 29.62 & \\
\hline
\end{tabular}

Studied areas: maize for silage under no-tillage (M7 years), maize for silage under conventional tillage (M20 years), annual pasture with chiseling (P3 years), annual pasture with chiseling (P15 years), permanent pasture without tillage (PP20 years), yerba mate without tillage (YM20 years), both compared to native forest (NF) and native pasture (NP). * CV: Coefficient of variation. Means followed by different letters in the column differ from each other by the $\mathrm{t}$ test $(\mathrm{P}<0.05)$.

The agricultural soil use in spite of the differences in times of manure application reduced the mineral associated organic carbon concentrations (MAOC) compared to the native forest, probably due to aggregates disruption in cultivated areas, exposing the carbon to the microbial action. Among the areas that receive organic fertilizer application, pastures with 3 and 20 years presented higher MAOC concentrations (Table 4). The MAOC is usually less affected by management, which may be related to its greater stabilization by association with the mineral fraction, decreasing its decomposition (BAYER \& MIELNICZUK, 1999).

In the mean of the three depths, the weighted average diameter (WAD) of aggregates in M7 was $5.17 \mathrm{~mm}$, followed by YM20 with $5.40 \mathrm{~mm}$, which were smaller than the other treatments, which had WAD similar to that of the native forest $(5.76 \mathrm{~mm}$ ) (Table 5), showing high aggregate stability. 
Table 4. Mineral associated organic carbon stock (MAOC, $\mathrm{Mg} \mathrm{ha}^{-1}$ ) in areas under different use and management systems under application of swine slurry and poultry manure on a Alfisol.

\begin{tabular}{|c|c|c|c|c|c|}
\hline \multirow{2}{*}{ Treatments } & \multicolumn{3}{|c|}{ Depths (cm) } & \multirow{2}{*}{$\begin{array}{c}\text { Sum } \\
\text { - }-20 \mathrm{~cm} \\
\end{array}$} & \multirow{2}{*}{ CV\%* } \\
\hline & $0-5$ & $5-10$ & 10-20 & & \\
\hline \multicolumn{6}{|c|}{ 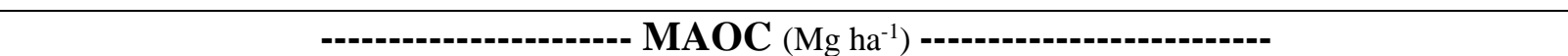 } \\
\hline M7 & $8.1 \mathrm{c}$ & $8.1 \mathrm{c}$ & $23.8 \mathrm{~b}$ & $40.0 \mathrm{de}$ & 13.21 \\
\hline M20 & $8.5 \mathrm{bc}$ & $8.2 \mathrm{bc}$ & $24.5 \mathrm{~b}$ & $41.4 \mathrm{~d}$ & 7.89 \\
\hline P3 & $9.6 \mathrm{~b}$ & $9.6 \mathrm{~b}$ & $29.0 \mathrm{a}$ & $48.2 \mathrm{~b}$ & 7.72 \\
\hline P15 & $8.1 \mathrm{c}$ & $8.0 \mathrm{c}$ & $24.7 \mathrm{~b}$ & $40.9 \mathrm{~d}$ & 8.82 \\
\hline PP20 & $9.0 \mathrm{bc}$ & $9.1 \mathrm{bc}$ & $27.9 \mathrm{a}$ & $46.0 \mathrm{bc}$ & 3.64 \\
\hline YM20 & $9.6 \mathrm{~b}$ & $8.8 \mathrm{bc}$ & $23.8 \mathrm{~b}$ & $42.3 \mathrm{~cd}$ & 10.24 \\
\hline $\mathrm{NF}$ & $14.0 \mathrm{a}$ & $18.0 \mathrm{a}$ & $30.0 \mathrm{a}$ & $62.1 \mathrm{a}$ & 10.64 \\
\hline $\mathrm{P} 0$ & $8.0 \mathrm{c}$ & $6.4 \mathrm{~d}$ & $21.9 \mathrm{~b}$ & $36.3 \mathrm{e}$ & 8.67 \\
\hline
\end{tabular}

Studied areas: maize for silage under no-tillage (M7 years), maize for silage under conventional tillage (M20 years), annual pasture with chiseling (P3 years), annual pasture with chiseling (P15 years), permanent pasture without tillage (PP20 years), yerba mate without tillage (YM20 years), both compared to native forest (NF) and native pasture (NP). Means followed by different letters in the column differ from each other by the $t$ test $(\mathrm{P}<0.05) . * \mathrm{CV}$ : Coefficient of variation.

The carbon concentrations in the different aggregate size classes was affected by the treatments. In the mean of the three depths, the greatest variation occurred between the reference treatment (NF) and M7 treatment, in the three evaluated aggregate classes. In the size class between 8.0 and $4.75 \mathrm{~mm}$, the variation between NF and M7 (treatments that obtained higher and lower carbon concentration, respectively) was $83 \%$. In the intermediate class (size 4.75 to $2 \mathrm{~mm}$ ) this variation was $100 \%$ and in the class of aggregates smaller than $2 \mathrm{~mm}$ this variation between NF and M7 was 140\%. This result may be related to the physical protection of carbon in the macroaggregates, reducing the decomposing action of microorganisms and their enzymes (BALESDENT et al., 2000).

In addition, Moreira \& Siqueira (2006) reported that soils submitted to periodic tillage, and showing compaction caused by machine traffic or animal trampling, can limit the growth and activity of microorganisms, altering the soil atmosphere and thus decreasing decomposition rate of organic matter. On the other hand, management practices with reduced tillage and high addition of organic residue to the surface can increase carbon content and improve physical, chemical and biological processes, resulting in high TOC concentrations and aggregate stability (ROSCOE et al., 2006).

Coarse aggregates (> $2.0 \mathrm{~mm}$ ) in the NF, P0 and P3 treatments had higher carbon contents (Table $5)$, in the mean of the three depths evaluated, in relation to the other treatments. 
Table 5. Weighted average diameter (WAD) and total organic carbon (TOC) in aggregates with diameter between 8.0 and $4.75 \mathrm{~mm}, 4.75$ and $2 \mathrm{~mm}$ and less than $2.0 \mathrm{~mm}$, at three depths in areas under different use and management systems with application of swine slurry and poultry manure on a Alfisol.

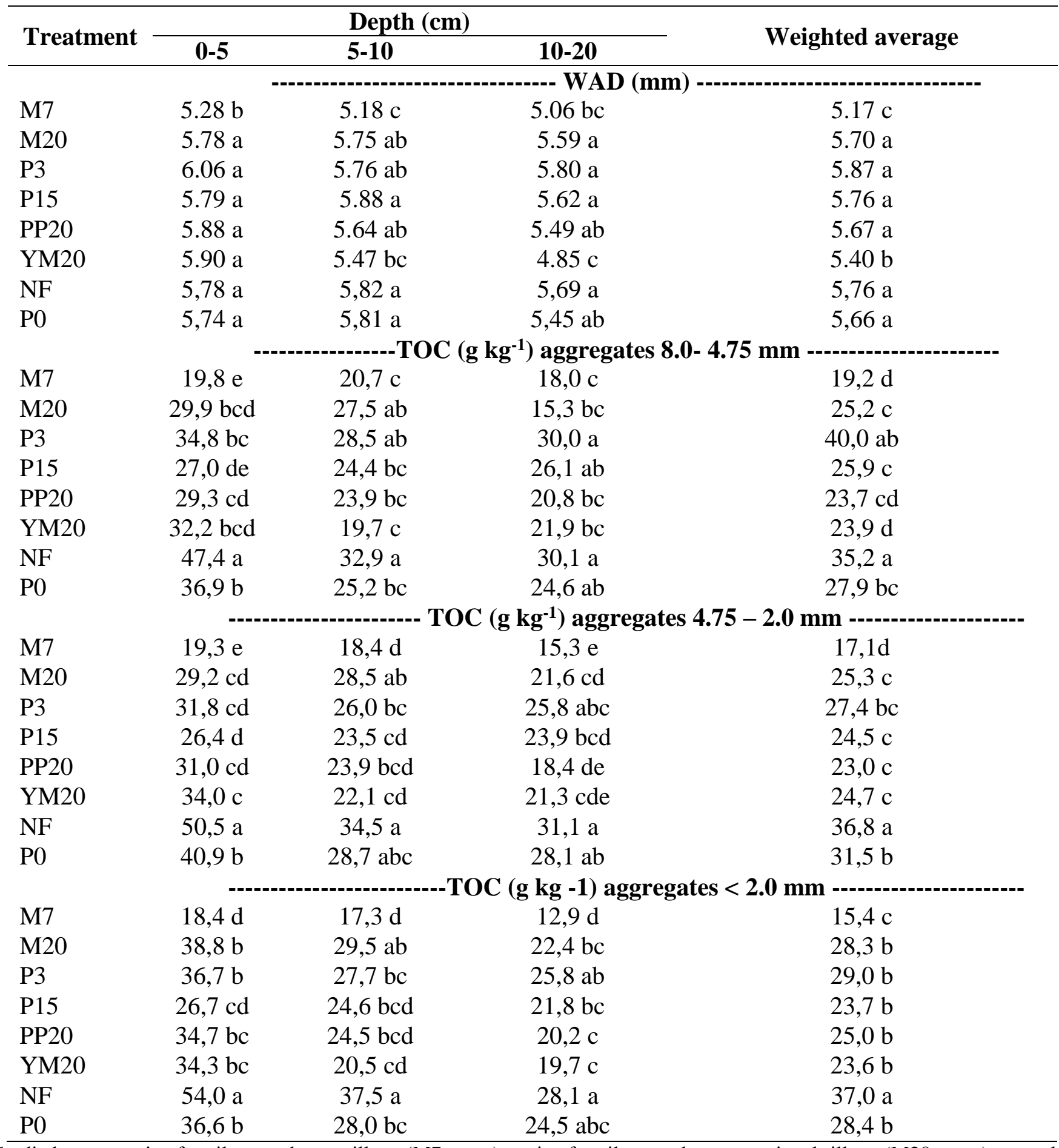

Studied areas: maize for silage under no-tillage (M7 years), maize for silage under conventional tillage (M20 years), annual pasture with chiseling (P3 years), annual pasture with chiseling (P15 years), permanent pasture without treatment (PP20 years), yerba mate without tillage (YM20 years), both compared to native forest (NF) and native pasture (NP). Letters in the column compare treatments by the $t$ test $(\mathrm{P}<0.05)$. 


\section{SOIL ORGANIC CARBON STOCKS IN GRANULOMETRIC FRACTIONS UNDER USE AND MANAGEMENT \\ SYSTEMS WITH SWINE AND POULTRY MANURE}

The permanent contribution of organic residues in these treatments together with the role of the root system in polysaccharide exudation may have contributed to the aggregation and stabilization of carbon in these aggregates. Treatment P3 represents a situation where soil use and fertilizer application is more recent, being similar to the reference condition (native forest).

The carbon management index (CMI) showed higher value in the P0 treatment (50.3) in relation to the other treatments, that had a CMI below 30 (with the exception of P3), indicating negative impact of the use and management practices on the organic matter contents. This index proposed by Blair et al. (1995), represents a relative measure of the changes caused by soil management, comparing a managed situation with one considered original or ideal, by measuring the changes in the TOC stocks.

Table 6. Carbon management index (CMI) in the 0-20 cm depth of a Alfisol, under different uses and management with swine slurry and poultry manure applications.

\begin{tabular}{lcccc}
\hline Treatments & CEI & L & LI & CMI \\
\hline M7 & 0.545 & 0.185 & 0.459 & 25.0 \\
M20 & 0.563 & 0.184 & 0.456 & 25.6 \\
P3 & 0.671 & 0.212 & 0.525 & 35.2 \\
P15 & 0.533 & 0.134 & 0.334 & 17.7 \\
PP20 & 0.587 & 0.113 & 0.281 & 16.4 \\
YM20 & 0.580 & 0.196 & 0.487 & 28.2 \\
NF & 1.000 & 0.403 & 1.000 & 100.0 \\
P0 & 0.567 & 0.358 & 0.889 & 50.3 \\
\hline
\end{tabular}

Areas studied: maize for silage under no-tillage (M7 years), maize for silage under conventional tillage (M20 years), annual pasture with chiseling (P3 years), annual pasture with chiseling (P15 years), permanent pasture without tillage (PP20 years), yerba mate without tillage (YM20 years), both compared to native forest (NF) and native pasture (NP). CEI: carbon efficiency index; L: lability; LI: lability index. CEI = TOCtreatment/ TOC native forest; LI = Ltreatment / Lnative forest; CMI = CEI x LI x 100

\section{CONCLUSIONS}

Soil carbon stocks under agricultural use and management systems reduced in comparison with native forest, and organic manure applications do not affect these carbon stocks.

The particulate soil carbon fraction is more sensitive to indicate differences caused by use and management systems, being affected by the time of animal manure application.

\section{REFERENCES}

ARRUDA, C.A.O.; ALVES, M.V.; MAFRA, A.L.; CASSOL, P.C.; ALBUQUERQUE, J.A.; SANTOS, J. C. P. 2010. Aplicação de dejeto suíno e estrutura de um Latossolo Vermelho sob semeadura direta.

Ciência e Agrotecnologia, Lavras, v.34, p.804-809. 
BALESDENT, J.; CHENU, C.; BALABANE, M. 2000. Relationship of soil organic matter dynamics to physical protection and tillage. Soil \& Tillage Research, Amsterdam, v.53, p.215-230.

BAYER, C.; MARTIN NETO, L.; MIELNICZUK, J.; PAVINATO, A. 2004. Armazenamento de carbono em frações lábeis da matéria orgânica de um Latossolo Vermelho sob plantio direto. Pesquisa Agropecuária Brasileira, Brasília, v.39, p.677-683.

BAYER, C.; MARTIN NETO, L.; MIELNICZUK, J.; PILLON, C.N.; SANGOI, L. 2001. Changes is soil organic matter fractions under subtropical no-till cropping systems. Soil Science Society of America Journal, Madison, v.65, p.1473-1478.

BAYER, C. \& MIELNICZUK, J. Dinâmica e função da matéria orgânica. In: SANTOS, G.A. \& CAMARGO, F.A.O. (Ed.). 1999. Fundamentos da matéria orgânica do solo: ecossistemas tropicais e subtropicais. Porto Alegre: Genesis, p.1-26.

BAYER, C.; MIELNICZUK, J.; AMADO, T.J.C.; NETO, L.M. 2000. Organic matter storage in a sandy clay loam Acrisol affected by tillage and cropping systems in southern Brazil. Soil \& Tillage Research, Amsterdam, v.54, p.101-109.

BAYER, C.; MIELNICZUK, J.; MARTIN NETO, L.; ERNANI, P.R. 2002. Stocks and humification degree of organic matter fractions as affected by no-tillage on a subtropical soil. Plant and Soil, Dordrecht, v.238, p.133-140.

BLAIR, G.J.; LEFROY, R.D.B.; LISLE, L. 1995. Soil carbon fractions based on their degree of oxidation, and the development of a carbon management index for agricultural systems. Australian Journal of Agricultural Research, Berlin, v.46:1459-1460, 1995.

BRANCALIÃO, S.R.; MORAES, M.H. 2008. Alterações de alguns atributos físicos e das frações húmicas de um Nitossolo Vermelho na sucessão milheto-soja em sistema plantio direto. Revista Brasileira de Ciência do Solo, Viçosa, v.32, p.393-404.

CAMBARDELLA, C.A.; ELLIOTT, E.T. 1992. Particulate soil organic-matter changes across a grassland cultivation sequence. Soil Science Society of America Journal, Madison, v.56, p.777-783.

CONCEIÇÃO, P.C.; AMADO, T.J.C.; MIELNICZUK, J.; SPAGNOLLO, E. Qualidade do solo em sistemas de manejo avaliada pela dinâmica da matéria orgânica e atributos relacionados. Revista Brasileira de Ciência do Solo, Viçosa, v.29, p.777-788.

EMBRAPA - Empresa Brasileira de Pesquisa Agropecuária. Sistema brasileiro de classificação de solos. 3.ed. Brasília: Embrapa, 2013. 353p.

EMBRAPA. Centro Nacional de Pesquisa de Solos. 2004. Solos do Estado de Santa Catarina. Rio de Janeiro, 726p. (Boletim de pesquisa e desenvolvimento, 46)

FUNDAÇÃO DO MEIO AMBIENTE - FATMA. Instrução normativa - 25 Suinocultura - 11/2009. Available at: www.fatma.sc.gov.br/IN_25 .pdf .Access in April,10 $10^{\text {th }}, 2016$.

GOLCHIN, A.; OADES, J.M.; SKJEMSTAD, J.O.; CLARKE, P. 1994. Soil structure and carbon cycling. Australian Journal of Soil Research, Sidney, v.32, p.1043-1068.

HOUGHTON, R.A.; SKOLE, D.L.; LEFKOWITZ, D.S. 1991. Changes in the landscape of Latin America between 1850 and 1985. II Net release of $\mathrm{CO}_{2}$ to the atmosphere. Forest Ecology and Management, v.38, p.173-199.

KEMPER, W.D.; CHEPIL, W.S. 1965. Size distribution of aggregation. In: BLACK, C.A. Methods of soil analysis. American Society Agronomy, Madison, p.499-510. (Agronomy Monoghaph, 9)

LOSS, A.; PEREIRA, M.G.; SCHULTZ, N.; ANJOS, L.H.C.; SILVA, E.M.R. 2009. Carbono e frações granulométricas da matéria orgânica do solo sob sistemas de produção orgânica. Ciência Rural, Santa Maria, v.39, p.1067-1072.

MOREIRA, F.M.S.; SIQUEIRA, J.O. Microbiologia e bioquímica do solo. 2.ed. Lavras: Universidade Federal de Lavras, 2006. 729p. 
RANGEL, O.J.P.; SILVA, C.A. 2007. Estoques de carbono e nitrogênio e frações orgânicas de Latossolo submetido a diferentes sistemas de uso e manejo. Revista Brasileira de Ciência do Solo, Viçosa, v.31, p.1609-1623.

ROSCOE, R.; MERCANTE, F.M.; SALTON, J.C. 2006. Dinâmica da matéria orgânica do solo em sistemas conservacionistas. Dourados: Embrapa Agropecuária Oeste, 304 p.

SAS - Institute INC.SAS 9.1.3 (TS1M3) for Windows Microsoft. (2007). Cary: SAS NC Institute.

SOCIEDADE BRASILEIRA DE CIÊNCIA DO SOLO. 2012. Pseudorepetições. Viçosa, SBCS, 40p. (Boletim informativo)

SCHERER, E. E.; BALDISSEREA, I.T.; DIAS, L.F.X. 1995. Caracterização e avaliação do adubo de estrume potencial suíno líquido região oeste Santa Catarina. Revista Agropecuária Catarinense, Florianópolis, v. 8, p.35-39.

SCHERER, E.E.; AITA, C.; BALDISSERA, I.T. 1996. Avaliação da qualidade do esterco líquido de suíno da região Oeste Catarinense para fins de utilização como fertilizante. Florianópolis, EPAGRI, 46p. (Boletim Técnico, 79)

SCHERER, E.E.; NESI, C.N.; MASSOTTI, Z. 2010. Atributos químicos do solo influenciados por sucessivas aplicações de dejetos suínos em áreas agrícolas de Santa Catarina. Revista Brasileira de Ciência do Solo, Viçosa, v.34, p.1375-1383.

TEDESCO, M.J.; GIANELLO, C.; BISSANI, C.A.; BOHNEN, H.; VOLKWEISS, S.J. 1995. Análises de solo, plantas e outros materiais. 2.ed. Porto Alegre: Universidade Federal do Rio Grande do Sul, $174 \mathrm{p}$.

VEZZANI, F.M.; MIELNICZUK, J. 2011. Agregação e estoque de carbono em Argissolo submetido a diferentes práticas de manejo agrícola. Revista Brasileira de Ciência do Solo, Viçosa, v.35, p.213223.

VIEIRA, F.C.B.; BAYER, C.; ZANATTA, J.A.; DIECKOW, J. MIELNICZUK, J.; HE, Z.L. 2007. Carbon management index based on physical fractionation of soil matter in an Acrisol under longterm no-till cropping systems. Soil e Tillage Research, Amsterdam, v.96, p.195-204.

Received in February 4, 2016 Accepted in July 11, 2017 